\title{
Effects of Nitrite and Toxic Microcystis Aeruginosa PCC7806 on the Growth of Freshwater Rotifer Brachionus Calyciflorus
}

\author{
Weimin Chen · Hao Liu $\cdot$ Qingmin Zhang • \\ Shugui Dai
}

Received: 27 January 2010/Accepted: 25 January 2011/Published online: 3 February 2011

(C) Springer Science+Business Media, LLC 2011

\begin{abstract}
Over the last two centuries, anthropogenic activities have increased the nitrogen amount in aquatic ecosystems, which has resulted in increased occurrences of blooms of cyanobacteria. This study investigated the effects of nitrite and the cyanobacterium Microcystis aeruginosa on population growth in the rotifer Brachionus calyciflorus. The rotifer was treated for 12 days with nitrite alone (medium containing 0,3, 6, $10 \mathrm{mg} \mathrm{NO}_{2}^{-}-\mathrm{N} \mathrm{L}^{-1}$ ), M. aeruginosa alone (medium containing $0 \mathrm{mg} \mathrm{NO}{ }_{2}^{-}$ $\mathrm{N} \mathrm{L}^{-1}+5.0 \times 10^{5}$ cell ml ${ }^{-1} M$. aeruginosa precultured at $\left.0,3,6,10 \mathrm{mg} \mathrm{NO}_{2}{ }^{-}-\mathrm{N} \mathrm{L}^{-1}\right)$, and nitrite in combination with $M$. aeruginosa (medium containing $3,10 \mathrm{mg} \mathrm{NO}_{2}{ }^{-}$ $\mathrm{N} \mathrm{L}^{-1}+5.0 \times 10^{5}$ cell $\mathrm{ml}^{-1} M$. aeruginosa precultured at corresponding nitrite concentrations). We observed that a nitrite concentration of $10 \mathrm{mg} \mathrm{NO}{ }_{2}^{-}-\mathrm{N} \mathrm{L}^{-1}$ markedly inhibited the growth of $B$. calyciflorus; however, rotifer growth declined slightly in the presence of $M$. aeruginosa precultured at $6 \mathrm{mg} \mathrm{NO}_{2}{ }^{-}-\mathrm{N} \mathrm{L}^{-1}$. Furthermore, reduced population growth of $B$. calyciflorus was observed when it was treated with both nitrite and M. aeruginosa compared to nitrite alone or $M$. aeruginosa alone. These results suggested that a high tolerance of $B$. calyciflorus to nitrite levels may be attributed to the absence of specific
\end{abstract}

W. Chen

College of Environment and Planning, Henan University,

475004 Kaifeng, People's Republic of China

H. Liu

Engineering Training Center, Tianjin University of Technology,

300384 Tianjin, People's Republic of China

Q. Zhang · S. Dai $(\bowtie)$

College of Environmental Science and Engineering, Nankai

University, 300071 Tianjin, People's Republic of China

e-mail: chenwm_env@yahoo.com.cn respiratory structures and pigments; and that the increased toxicity of nitrite in combination with $M$. aeruginosa may have been due to increased production of microcystin. It is also possible that nitrite and microcystin could act in a synergistic way in causing toxicity.

Keywords Growth - Microcystin · Nitrite ·

Brachionus calyciflorus $\cdot$ Microcystis aeruginosa

During the past two centuries, and especially over the last five decades, humans have substantially altered the global nitrogen cycle, increasing both the availability and the mobility of nitrogen over large regions of earth (Galloway and Cowling 2002). Consequently, a large amount of inorganic and organic nitrogen can enter aquatic ecosystems and result in increased concentrations of inorganic nitrogen in surface water (Rouse et al. 1999; Smith et al. 1999; Li et al. 2009). Nutrient concentration plays an important role in the growth of phytoplankton, and generally a combination of high nutrient load with warm, stable condition can stimulate phytoplankton to grow excessively and form blooms (Paerl 1988). Microcystis aeruginosa blooms are common and widespread in eutrophied freshwater ecosystems. Some studies have revealed that many strains of this cyanobacterium produce microcystins, which pose a threat to humans by hepatotoxicity and inhibition of protein phosphatase types 1 and $2 \mathrm{~A}$ (Mackintosh et al. 1990; Dawson 1998). The increase of nitrogen in aquatic ecosystem can also cause significant enhancement of nitrite concentration due to imbalances in nitrification and denitrification processes (Philips et al. 2002), In addition, certain human activities direct increase the amount of nitrite, such as industrial wastewater effluents, municipal sewage effluents, runoff from agriculture 
(Lewis and Morris 1986; Camargo and Alonso 2006; Li et al. 2009). On the basis of acute toxicity data, several authors have suggested nitrite levels over $0.35 \mathrm{mg} \mathrm{NO}-$ $\mathrm{N} \mathrm{L}^{-1}$ were toxic to sensitive aquatic animals (Camargo and Alonso 2006), causing dysfunctions of the oxygen carrying pigments, as well as reductions in extracellular chloride concentration and muscle potassium content (Lewis and Morris 1986; Philips et al. 2002; Camargo and Alonso 2006).

Zooplankton groups, particularly rotifers, cladocerans and copepods, represent the dominant component in freshwater bodies and are the natural food link between the primary producer (algae) and zooplanktivorous fish (Pennak 1989). As such they are important in the maintenance of an ecological balance in fresh water ecosystems. Although numerous studies have examined the effects of microcystin produced by $M$. aeruginosa on zooplankton, few studies have focused on rotifers (Smith and Gilbert 1995; Nandini 2000; Geng et al. 2006). Moreover, there is little information on the influence of nitrite on rotifers and microcystin toxicity. Thus, in the present study, we examined the effects of nitrite and $M$. aeruginosa alone and in combination, upon the growth in a laboratory culture of the rotifer Brachionus calyciflorus.

\section{Materials and Methods}

B. calyciflorus was collected from Lake Taihu (China) and maintained in the laboratory for 6 months prior to initiation of this experiment. A clone of this species was derived from a single female and cultured in EPA medium (Teresa et al. 2004) at $25^{\circ} \mathrm{C}, 300$ lux and a $12 \mathrm{~h}$ light: $12 \mathrm{~h}$ dark cycle, on a diet of $5.0 \times 10^{5}$ cell ml ${ }^{-1}$ Scenedesmus obliquus. M. aeruginosa PCC7806 and S. obliquus were obtained from the Institute of Hydrobiology, Chinese Academy of Sciences (Wuhan, China). M. aeruginosa PCC7806, which produces microcystin-LR (Downing et al. 2005), was grown in the sterilized modified BG-11 medium, where nitrate concentration was $50 \mathrm{mg} \mathrm{NO}-\mathrm{N}_{3}^{-1}$ (Chen et al. 2009), at $25^{\circ} \mathrm{C}, 2500$ lux and a $12 \mathrm{~h}$ light: $12 \mathrm{~h}$ dark cycle. $S$. obliquus was cultured in sterilized HB-4 medium (Ma et al. 2004) under similar condition. Cell densities were monitored by enumeration with microscope and hemacytometer.

The experiment followed a factorial design with two factors, nitrite and $M$. aeruginosa. It investigated the effects of nitrite alone, M. aeruginosa alone and M. aeruginosa in combination with nitrite on $B$. calyciflorus. The effect of nitrite on $B$. calyciflorus experiment was carried out in four nitrite treatments $\left(0,3,6,10 \mathrm{mg} \mathrm{NO}_{2}^{-}-\mathrm{N} \mathrm{L}^{-1}\right)$ achieved by adding $\mathrm{NaNO}_{2}$ to the EPA medium, based on the range of
nitrite-N concentration reported by Masser et al. (1999), Spieles and Mitsch (2000) and Li et al. (2009).

To investigate the impact of $M$. aeruginosa on B. calyciflorus, $M$. aeruginosa was precultured in modified BG-11 medium with $0,3,6,10 \mathrm{mg} \mathrm{NO}_{2}^{-}-\mathrm{N} \mathrm{L}^{-1}$. The nitrite concentration of medium was held constant by adding nitrite daily. The initial cell density was about $5 \times 10^{4}$ cell ml ${ }^{-1}$. After 9 days of precultivation, the algae were harvested, centrifuged at $3,000 \mathrm{~g}$ for $10 \mathrm{~min}$, and transferred to EPA medium to form four different treatments: $0 \mathrm{mg} \mathrm{NO}_{2}^{-}-\mathrm{N} \mathrm{L}^{-1}+5.0 \times 10^{5}$ cell ml $^{-1}$ $M$. aeruginosa precultured at $0,3,6,10 \mathrm{mg} \mathrm{NO}_{2}^{-}-\mathrm{N} \mathrm{L}^{-1}$; the experiment of effect of nitrite in combination with $M$. aeruginosa on $B$. calyciflorus had two nitrite levels of 3 and $10 \mathrm{mg} \mathrm{NO}_{2}^{-}-\mathrm{N} \mathrm{L}^{-1}$. After preculturing at these two nitrite levels for 9 days, $M$. aeruginosa was transferred to EPA medium with 3 and $10 \mathrm{mg} \mathrm{NO}_{2}^{-}-\mathrm{N} \mathrm{L}^{-1}$, respectively to achieve two treatments: $3 \mathrm{mg} \mathrm{NO}_{2}^{-}-\mathrm{N} \mathrm{L}^{-1}+5.0 \times 10^{5}$ cell $\mathrm{ml}^{-1} M$. aeruginosa precultured at $3 \mathrm{mg} \mathrm{NO}_{2}^{-}-\mathrm{N} \mathrm{L}^{-1}$, $10 \mathrm{mg} \mathrm{NO}_{2}^{-}-\mathrm{N} \mathrm{L}^{-1}+5.0 \times 10^{5}$ cell ml ${ }^{-1} M$. aeruginosa precultured at $10 \mathrm{mg} \mathrm{NO}_{2}^{-}-\mathrm{N} \mathrm{L}^{-1}$.

All experiments were conducted on a diet of $5.0 \times 10^{5}$ cell $\mathrm{ml}^{-1} \mathrm{~S}$. obliquus at $25^{\circ} \mathrm{C}, 300 \mathrm{lux}$ and a $12 \mathrm{~h}$ light: $12 \mathrm{~h}$ dark cycle. Five neonates ( $<6 \mathrm{~h}$ old) were introduced in $20 \mathrm{ml}$ glass beakers containing $10 \mathrm{ml}$ designated treatment medium. The animals were transferred daily to fresh treatment medium, and the numbers of all live individuals were recorded. The experiments were terminated after 12 days. Every treatment had three replicates. Based on population abundance data, the growth rate $(r)$ was calculated using the equation $r=\ln \left(\mathrm{N}_{\mathrm{t}} / \mathrm{N}_{0}\right) / \mathrm{t}$, where $\mathrm{N}_{0}$ is the initial population density and $\mathrm{N}_{\mathrm{t}}$ is the population density after $t$ days. Data of the maximum population density and $r$ were treated statistically using one-way analysis of variance (ANOVA). Post hoc pairwise comparisons were performed (Tukey test) to compare a given treatment to all other treatments in every experiment. A probability of $p<0.05$ was considered statistically significant. All analyses were performed with SPSS.

\section{Results and Discussion}

The population density and growth rate of $B$. calyciflorus at different nitrite concentrations are presented in Fig. 1 and Table 1. There were no significant impacts at nitrite concentrations of 0,3 and $6 \mathrm{mg} \mathrm{NO}_{2}^{-}-\mathrm{N} \mathrm{L}^{-1}$ on $B$. calyciflorus $(p>0.05)$, but a statistically significant inhibition on growth of $B$. calyciflorus was observed at nitrite concentration of $10 \mathrm{mg} \mathrm{NO}--\mathrm{N} \mathrm{L}^{-1}(p<0.05)$, where the growth rate and maximum population density decreased by 2.9 and $19 \%$, respectively compared to $0 \mathrm{mg} \mathrm{NO}_{2}^{-}-\mathrm{N} \mathrm{L}^{-1}$. 


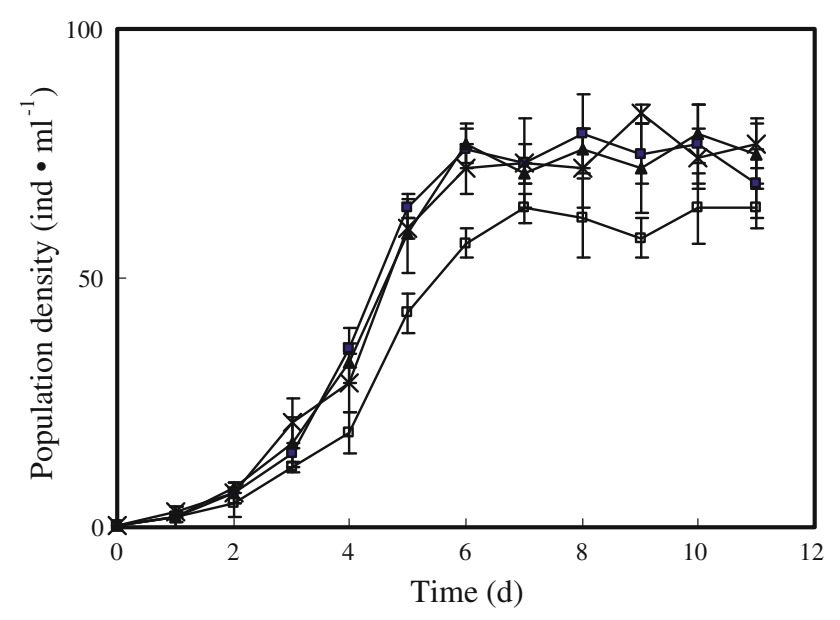

Fig. 1 The population density of Branchionus calyciflorus in nitrite treatments. $0 \mathrm{mg} \mathrm{NO}_{2}{ }^{-}-\mathrm{N} \mathrm{L}^{-1}$ filled square, $3 \mathrm{mg} \mathrm{NO}_{2}{ }^{-}-\mathrm{N} \mathrm{L}^{-1}$ filled triangle, $6 \mathrm{mg} \mathrm{NO}_{2}{ }^{-}-\mathrm{N} \mathrm{L}^{-1}$ times symbol, $10 \mathrm{mg} \mathrm{NO}_{2}{ }^{-}-\mathrm{N} \mathrm{L}^{-1}$ square. Error bars denote the standard deviation of triplicate incubations

The study of population growth is commonly used to evaluate the effects of many substances such as pesticide and heavy metals to zooplankton. In general, a reduction in the growth rate indicates that a substance is toxic to zooplankton (Forbes and Calow 1999). Therefore, the present study suggested the nitrite concentration of $10 \mathrm{mg} \mathrm{NO}_{2}^{-}-\mathrm{N} \mathrm{L}^{-1}$ caused toxicity to $B$. calyciflorus. Many laboratory studies have examined nitrite concentration inducing toxicity to freshwater invertebrates and fishes. These studies revealed Cherax quadricarinatus (decapod; adult), Oncorhynchus mykiss (salmonid; fry), Pimephales promelas (cyprinid; fry), Hexagenia sp (ephemeropteran; larvae) and Gammarus fasciatus (amphipod; adult) exhibited acute toxicity (96-hour
$\mathrm{LC}_{50}$ ) lower than $3 \mathrm{mg} \mathrm{NO}-\mathrm{N} \mathrm{L}^{-1}$ (Russo et al. 1981; Ewell et al. 1986; Rouse et al. 1995; Camargo and Alonso 2006). Compared to B. calyciflorus, these species seemed to be more sensitive to nitrite, possibly resulting from a difference in respiratory structures between $B$. calyciflorus and these species. C. quadricarinatus, O. mykiss, P. promelas, $H$. $s p$ and G. fasciatus have gills and singular oxygen-carrying pigments. In contrast, $B$. calyciflorus has no specific respiratory structures and pigments, and the gas exchange is performed by simple diffusion through the body wall. The gills are the organs of active nitrite uptake, there is strong evidence that nitrite toxicity to aquatic animal is mitigated when inhibition of active diffusion of nitrite through the gill occurs (Russo et al. 1981; Lewis and Morris 1986; Camargo and Alonso 2006; Alonso and Camargo 2008). In addition, nitrite could cause the conversion of oxygen-carrying pigments to a form that is incapable of carrying oxygen (Lewis and Morris 1986; Philips et al. 2002; Camargo and Alonso 2006). Hence, the absence of these respiratory structures could be the reason for the high tolerance of $B$. calyciflorus to nitrite toxicity (Alonso and Camargo 2008).

Figure 2 and Table 1 show the effects of $M$. aeruginosa precultured at different nitrite concentrations on $B$. calyciflorus. The growth of animals in medium with $M$. aeruginosa precultured at 0 and $3 \mathrm{mg} \mathrm{NO}-\mathrm{N} \mathrm{L}^{-1}$ did not exhibit significant change $(p>0.05)$. However, the population growth of $B$. calyciflorus was statistically significantly inhibited in the presence of $M$. aeruginosa precultured at 6 and $10 \mathrm{mg} \mathrm{NO}-\mathrm{N} \mathrm{L}^{-1}(p<0.05)$.

As mentioned in the introduction, microcystin has been found to be toxic to humans, animals and plants. Some laboratory investigations have demonstrated that though B. calyciflorus was tolerant to microcystin to some extent,

Table 1 Maximum population density and growth rate of Branchionus calyciflorus in different treatments. Data are means \pm SD ( $\mathrm{n}=3$ )

\begin{tabular}{lccc}
\hline Nitrite $\left(\mathrm{mg} \mathrm{NO}_{2}{ }^{-}-\mathrm{N} \mathrm{L}^{-1}\right)$ & & $\begin{array}{l}\text { Growth rate } \\
\left(\text { days }^{-1}\right)\end{array}$ & $\begin{array}{l}\text { Maximum population } \\
\left.\text { density(ind. } \mathrm{mL}^{-1}\right)\end{array}$ \\
\hline Nitrite treatments & 0 & $0.454 \pm 0.006$ & $79 \pm 5$ \\
& 3 & $0.456 \pm 0.010$ & $79 \pm 6$ \\
& 6 & $0.458 \pm 0.005$ & $83 \pm 9$ \\
& 10 & $0.441 \pm 0.003^{\mathrm{a}}$ & $64 \pm 7^{\mathrm{a}}$ \\
M. aeruginosa treatments & 0 & $0.456 \pm 0.008$ & $80 \pm 11$ \\
& 3 & $0.460 \pm 0.006$ & $69 \pm 8^{\mathrm{b}}$ \\
Nitrite in combination with & 6 & $0.443 \pm 0.006^{\mathrm{b}}$ & $50 \pm 5^{\mathrm{b}}$ \\
M. aeruginosa treatments & 10 & $0.413 \pm 0.011^{\mathrm{b}}$ & $65 \pm 6^{\mathrm{c}}$ \\
\hline
\end{tabular}

\footnotetext{
a significant difference with the $0,3,6 \mathrm{mg} \mathrm{NO}_{2}{ }^{-}-\mathrm{N} \mathrm{L}^{-1}$ in nitrite treatments

b significant difference with the $0,3 \mathrm{mg} \mathrm{NO}_{2}{ }^{-}-\mathrm{N} \mathrm{L}^{-1}$ in $M$. aeruginosa treatments

c significant difference with the $3 \mathrm{mg} \mathrm{NO}_{2}{ }^{-}-\mathrm{N} \mathrm{L}^{-1}$ in $M$. aeruginosa treatments and in nitrite treatments

${ }^{\mathrm{d}}$ significant difference with the $10 \mathrm{mg} \mathrm{NO}_{2}{ }^{-}-\mathrm{N} \mathrm{L}^{-1}$ in M. aeruginosa treatments and in nitrite treatments $\left({ }^{\mathrm{a}, \mathrm{b}, \mathrm{c}, \mathrm{d}} p<0.05\right)$
} 


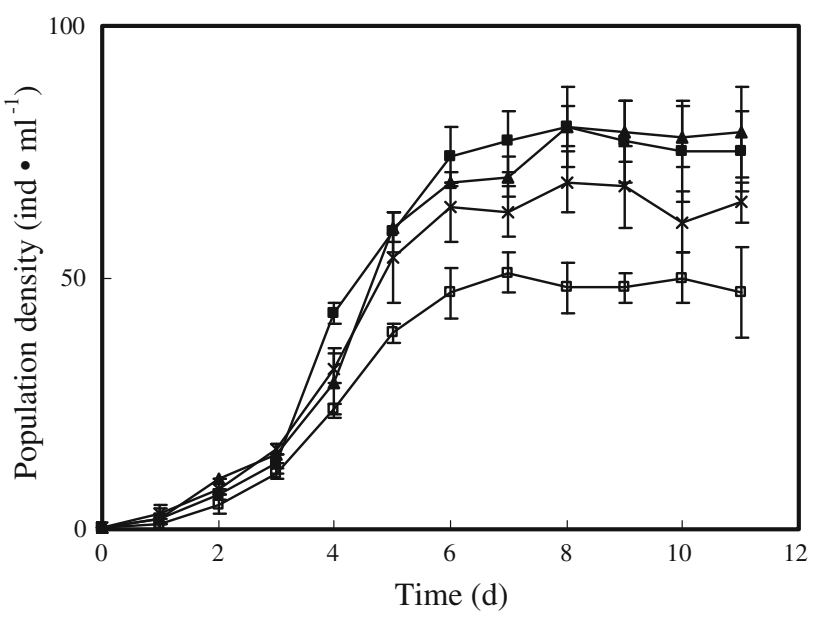

Fig. 2 The population density of Branchionus calyciflorus in $M$. aeruginosa treatments. $0 \mathrm{mg} \mathrm{NO}{ }^{-}-\mathrm{N} \mathrm{L}^{-1}+5.0 \times 10^{5}$ cell ml${ }^{-1}$ M. aeruginosa precultured at 0 filled square, 3 filled triangle, 6 times symbol and 10 square $\mathrm{mg} \mathrm{NO}_{2}{ }^{-}-\mathrm{N} \mathrm{L}^{-1}$. Error bars denote the standard deviation of triplicate incubations

its growth was adversely inhibited by microcystin at M. aeruginosa concentration of $10^{6}$ cells $\mathrm{ml}^{-1}$ (Smith and Gilbert 1995; Nandini 2000; Geng et al. 2006). Therefore, we propose that the decreased population growth of rotifers in the presence of $M$. aeruginosa precultured at 6 and $10 \mathrm{mg} \mathrm{NO}-\mathrm{N} \mathrm{L}^{-1}$ indicates a higher amount of microcystin. This would indicate an increase in toxin production per cell, given the equal cell density of all $M$. aeruginosa treatments. The production of toxin by algae has been suggested to have special biological functions, and can be governed by biotic and abiotic factors, such as temperature, $\mathrm{pH}$, light intensity, nutrient concentration, zooplankton and fish (Westhuizen and Eloff 1985; Downing et al. 2005; MarÍa and Daniel 2005). Recently, Jang et al. (2004, 2006) and Gong et al. (2009) reported some chemicals that could stimulate microcystin production of $M$. aeruginosa. Moreover, our previous work found that high nitrite concentration caused a significant increase in MC-LR of M. aeruginosa (Chen et al. 2010). Thus, it is reasonable to hypothesize that nitrite stimulated microcystin production in the algae, and the increasing toxin concentration resulted in the suppression of population growth in B. calyciflorus.

In comparing the effect of $3 \mathrm{mg} \mathrm{NO}-\mathrm{N} \mathrm{L}^{-1}$ in combination with $M$. aeruginosa on $B$. calyciflorus to the medium with $3 \mathrm{mg} \mathrm{NO}{ }_{2}^{-}-\mathrm{N} \mathrm{L}^{-1}$ or $M$. aeruginosa precultured at $3 \mathrm{mg} \mathrm{NO}_{2}{ }^{-}-\mathrm{N} \mathrm{L}^{-1}$ alone, a significant decrease in population growth of $B$. calyciflorus was observed in the combination treatment of $3 \mathrm{mg} \mathrm{NO}-\mathrm{N}_{2}^{-1}$ and M. aeruginosa precultured and tested in $3 \mathrm{mg} \mathrm{NO}-\mathrm{N}_{2}^{-}-\mathrm{N} \mathrm{L}^{-1}$ (Table 1; Fig. $3 ; p<0.05$ ). Treatments of $3 \mathrm{mg} \mathrm{NO} \mathrm{NO}_{2}^{-}$ $\mathrm{N} \mathrm{L}^{-1}$ alone or M. aeruginosa alone precultured at $3 \mathrm{mg}$ $\mathrm{NO}_{2}^{-}-\mathrm{N} \mathrm{L}^{-1}$ did not result in significant population growth differences $(p>0.0 .05)$. Similarly, the growth of animals
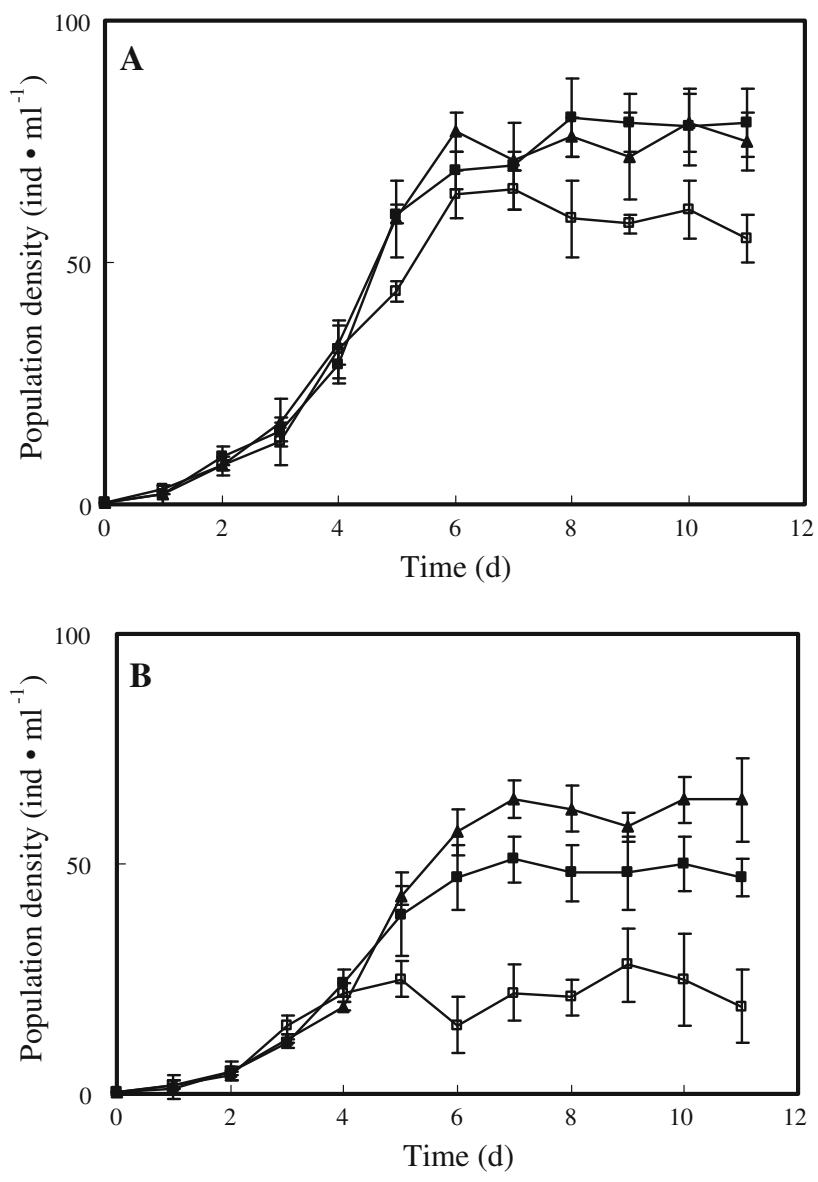

Fig. 3 The population density of Branchionus calyciflorus in nitrite in combination with $M$. aeruginosa treatments and corresponding nitrite treatments, $M$. aeruginosa treatments. a $3 \mathrm{mg} \mathrm{NO}_{2}{ }^{-}-\mathrm{N} \mathrm{L}^{-1}$ filled triangle, $0 \mathrm{mg} \mathrm{NO}{ }^{-}-\mathrm{N} \mathrm{L}^{-1}+5.0 \times 10^{5}$ cell ml ${ }^{-1} M$. aeruginosa precultured at $3 \mathrm{mg} \mathrm{NO}{ }^{-}-\mathrm{N} \mathrm{L}^{-1}$ filled square, $3 \mathrm{mg} \mathrm{NO}_{2}^{-}$ $\mathrm{N} \mathrm{L}^{-1}+5.0 \times 10^{5}$ cell ml${ }^{-1} M$. aeruginosa precultured at $3 \mathrm{mg}$

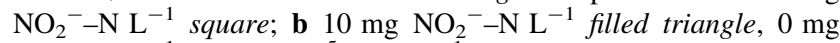
$\mathrm{NO}_{2}{ }^{-}-\mathrm{N} \mathrm{L}^{-1}+5.0 \times 10^{5}$ cell ml ${ }^{-1} M$. aeruginosa precultured at $10 \mathrm{mg} \mathrm{NO}{ }^{-}-\mathrm{N} \mathrm{L}^{-1}$ filled square, $10 \mathrm{mg} \mathrm{NO}_{2}{ }^{-}-\mathrm{N} \mathrm{L}^{-1}+5.0 \times 10^{5}$ cell $\mathrm{ml}^{-1} M$. aeruginosa precultured at $10 \mathrm{mg} \mathrm{NO}_{2}{ }^{-}-\mathrm{N} \mathrm{L}^{-1}$ square. Error bars denote the standard deviation of triplicate incubations

in the medium with both $10 \mathrm{mg} \mathrm{NO}_{2}^{-}-\mathrm{N} \mathrm{L}^{-1}$ and M. aeruginosa precultured at $10 \mathrm{mg} \mathrm{NO}_{2}^{-}-\mathrm{N} \mathrm{L}^{-1}$ showed a greater inhibition than the medium with $10 \mathrm{mg} \mathrm{NO}_{2}^{-}$ $\mathrm{N} \mathrm{L}^{-1}$ alone, or M. aeruginosa precultured at $10 \mathrm{mg} \mathrm{NO}_{2}^{-}-$ $\mathrm{N} \mathrm{L}^{-1}$ alone(Table 1; Fig. 3; $p<0.05$ ).

The influence of different abiotic and biotic factors on the toxicity of nitrite or microcystin is a subject of continued interest from different investigators. For example, the presence of chloride, calcium and selenium in the ambient water may significantly reduce nitrite toxicity to aquatic animals (Russo et al. 1981; Lewis and Morris 1986; Wang et al. 2009). Dithioerythrito and silymarinand protected against microcystin-induced toxicity toward cultured rat hepatocytes (Mereish and Solow 1990). The present study examining the mutual influence of nitrite and 
microcystin showed that nitrite in combination with $M$. aeruginosa caused a greater reduction in population growth than either nitrite treatment alone or $M$. aeruginosa treatment alone.

In summary, B. calyciflorus showed a high tolerance to nitrite toxicity, possibly owing to the absence of respiratory structures and pigments. $M$. aeruginosa precultured at higher nitrite levels (6 and $10 \mathrm{mg} \mathrm{NO}_{2}^{-}-\mathrm{N} \mathrm{L}^{-1}$ ) showed inhibition of population growth in B. calyciflorus, likey caused by promotion of algal growth and increased production of microcystin. In addition, the possibility exists that nitrite and microcystin could act synergistically in causing the observed toxicity. This suggests that the influence of $M$. aeruginosa on the toxicity of nitrite should be taken into account when the ecotoxicological risk assessment of nitrite is performed in aquatic ecosystems, and vice versa.

Acknowledgments This work was supported by a cooperative project between Nankai University and Tianjin University funded by Educational Ministry of China.

\section{References}

Alonso A, Camargo JA (2008) Ameliorating effect of chloride on nitrite toxicity to freshwater invertebrates with different physiology: a comparative study between amphipods and planarians. Arch Environ Contam Toxicol 54:259-265

Camargo JA, Alonso A (2006) Ecological and toxicological effects of inorganic nitrogen pollution in aquatic ecosystems: a global assessment. Environ Int 32:831-849

Chen WM, Zhang QM, Dai SG (2009) Effects of nitrate on intracellular nitrite and growth of Microcystis aeruginosa. J Appl Phycol 21:701-706

Chen WM, Liu H, Zhang QM et al. (2010) Effect of nitrite on growth and microcystins production of Microcystis aeruginosa PCC7806. J Appl Phycol doi:10.1007/s10811-010-9558-y

Dawson RM (1998) Toxicology of microcystins. Toxicon 7:953-962

Downing TG, Sember CS, Gehringer MM et al (2005) Medium N:P ratios and specific growth rate comodulate microcystin and protein content in Microcystis aeruginosa PCC7806 and M. aeruginosa UV027. Microb Ecol 49:468-473

Ewell WS, Gorsuch JW, Kringle RO et al (1986) Simultaneous evaluation of the acute effects of chemicals on seven aquatic species. Environ Toxicol Chem 5:831-840

Forbes VE, Calow P (1999) Is the per capita rate of increase a good measure of population-level effects in ecotoxicology? Environ Toxicol Chem 18:1544-1556

Galloway JN, Cowling EB (2002) Reactive nitrogen and the world: 200 years of change. Ambio 31:64-71

Geng H, Xie P, Xu J (2006) Effect of toxic Microcystis aeruginosa PCC7820 in combination with a green alga on the experimental population of Brachionus calyciflorus and B. rubens. Bull Environ Contam Toxicol 76:963-969

Gong Y, Chou HN, Tu CD et al (2009) Effects of arsenate on the growth and microcystin production of Microcystis aeruginosa isolated from Taiwan as influenced by extracellular phosphate. J Appl Phycol 21:225-231

Jang MH, Ha K, Joo GJ et al (2004) Changes in microcystin production by Microcystis aeruginosa exposed to phytoplanktivorous and omnivorous fish. Aquat Toxicol 68:51-58
Jang MH, Ha K, Jung JM et al (2006) Increased microcystin production of Microcystis aeruginosa by indirect exposure to nontoxic cyanobacteria: potential role in the development of Microcystis bloom. Bull Environ Contam Toxicol 76:957-962

Lewis WM, Morris DP (1986) Toxicity of nitrite to fish: a review. Trans Am Fish Soc 115:183-195

Li YF, Wan WF, Song J et al (2009) Classification of groundwater contamination in Yuxi river valley, Shaanxi Province, China. Bull Environ Contam Toxicol 82:234-238

Ma JY, Lin FC, Zhang RZ et al (2004) Differential sensitivity of two green algae, Scenedesmus quadricauda and Chlorella vulgaris, to 14 pesticide adjuvants. Ecotoxicol Environl Saf 58:61-67

Mackintosh C, Beattie KA, Klump S et al (1990) Cyanobacterial microcystin-LR is a potent and specific inhibitor of protein phosphatases 1 and 2A from both mammals and higher plants. FEBS Lett 264:187-192

MarÍa VA, Daniel AW (2005) Effects of iron, ammonium and temperature on microcystin content by a natural concentrated Microcystis aeruginosa population. Water Air Soil Pollut 168: 235-248

Masser MP, Rakocy J, Losordo TM (1999) Recirulating aquaculture tank production system: management of recirculating systems. SRAC Publ 452 (Aubum, $11 \mathrm{pp}$ )

Mereish KA, Solow R (1990) Effect of antihepatotoxic agents against microcystin-LR toxicity in cultured rat hepatocytes. Pharm Res 7(3):256-259

Nandini S (2000) Responses of rotifers and cladocerans to Microcystis aeruginosa (cyanophyceae): a demographic study. Aquat Ecol 34:227-242

Paerl HW (1988) Nuisance phytoplankton blooms in coastal estuarine inland waters. Limnol Oceanogr 33:823-847

Pennak RW (1989) Fresh-water invertebrates of the United States. The Ronald-Press Co, New York

Philips S, Laanbroek JH, Verstraete W (2002) Origin, causes and effects of increased nitrite concentrations in aquatic environments. Rev Environ Sci Biotechnol 1:115-141

Rouse DB, Kastner RJ, Reddy KS (1995) Toxicity of ammonia and nitrite to hatching redclaw crayfish, Cherax quadricarinatus. Freshw Crayfish 10:298-303

Rouse JD, Bishop CA, Struger J (1999) Nitrogen pollution: an assessment of its threat to amphibian survival. Environ Health Perspect 107:799-803

Russo RC, Thurston RV, Emerson K (1981) Acute toxicity of nitrite to rainbow trout (Salmo gairdneri): effects of $\mathrm{pH}$, nitrite species, and anion species. Can J Fish Aquat Sci 38:387-393

Smith AD, Gilbert JJ (1995) Relative susceptibilities of rotifers and cladocerans to Microcystis aeruginosa. Arch Hydrobiol 132: 309-336

Smith VH, Tilman GD, Nekola JC (1999) Eutrophication: impacts of excess nutrient inputs on freshwater, marine, and terrestrial ecosystems. Environ Pollut 100:179-196

Spieles DJ, Mitsch WJ (2000) The effects of season and hydrologic and chemical loading on nitrate retention in constructed wetlands: a comparison of low-and high-nutrient riverine systems. Ecol Eng 14:77-91

Teresa RP, Sarma SSS, Nandini S (2004) Effects of mercury on the life table demography of the rotifer Brachionus calyciflorus Pallas (rotifera). Ecotoxicology 13:535-544

Wang HW, Xu HM, Xiao GH et al (2009) Effects of selenium on the antioxidant enzymes response of Neocaridins heteropoda exposed to ambient nitrite. Bull Environ Contam Toxicol 84(1): $112-117$

Westhuizen AJV, Eloff JN (1985) Effect of temperature and light on the toxicity and growth of the blue-green alga Microcystis aeruginosa (UV-006). Planta 163:55-59 